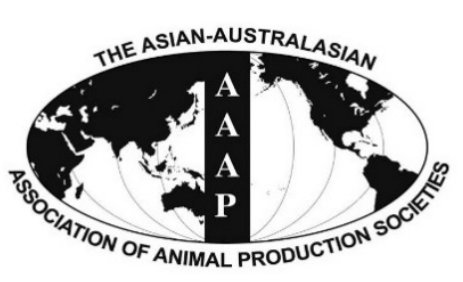

Open Access

Asian Australas. J. Anim. Sci.

Vol. 28, No. 9 : 1327-1334 September 2015

http://dx.doi.org/10.5713/ajas.14.0914

www.ajas.info

pISSN 1011-2367 elSSN 1976-5517

\title{
Apparent or Standardized Ileal Digestibility of Amino Acids of Diets Containing Different Protein Feedstuffs Fed at Two Crude Protein Levels for Growing Pigs
}

\author{
A. O. Adebiyi*, D. Ragland ${ }^{1}$, O. Adeola ${ }^{2}$, and O. A. Olukosi \\ Avian Science Research Centre, Scotland's Rural College, Ayr, KA6 5HW, UK
}

\begin{abstract}
The current study determined the apparent or standardized ileal digestibility of amino acids (AID or SID of AA) in growing pigs fed diets containing three protein feedstuffs with different fiber characteristics at two dietary crude protein (CP) levels. Twenty boars (Yorkshire $\times$ Landrace) with average initial body weight of $35( \pm 2.6) \mathrm{kg}$ were fitted with a simple T-cannula at the distal ileum. These pigs were offered six diets containing soybean meal (SBM), canola meal (CM) or corn distillers dried grains with solubles (corn-DDGS) that were either adequate $(19 \%)$ or marginal $(15 \%)$ in CP using a triplicated $6 \times 2$ Youden Square Design. Except for Met, Trp, Cys, and Pro, AID of AA was greater $(\mathrm{p}<0.05)$ in the SBM diet compared with the CM diet. Apparent ileal digestibility for Gly and Asp was greater $(\mathrm{p}<0.05)$ in the SBM diet compared with the corn-DDGS diet. The AID of Ile, Leu, Phe, Val, Ala, Tyr, and Asp was greater $(p<0.05)$ in the corn-DDGS diet compared with the CM diet. Standardized ileal digestibility of AA was greater $(p<0.05)$ in the SBM diet compared with the CM diet for all AA except Trp and Pro. The SID of Ile, Leu, Val, Ala, Tyr, and Asp was greater ( $\mathrm{p}<0.05)$ in the corn-DDGS diet compared with the CM diet. It was concluded that protein feedstuff affects ileal AA digestibility and is closely related to dietary fiber characteristics, and a 4-percentage unit reduction in dietary CP had no effect on ileal AA digestibility in growing pigs. (Key Words: Amino Acids Digestibility, Crude Protein Level, Growing Pigs, Protein Feedstuff)
\end{abstract}

\section{INTRODUCTION}

Fiber is a usual component in the pig diet and when included within reasonable levels, it promotes normal gastrointestinal tract function (Wenk, 2001). On the other hand, the negative effect of dietary fiber on energy and nutrient utilization is dependent on its physical and chemical properties which differ among feedstuffs (Lenis et al., 1996). Cereal grains usually contribute the majority of fiber to the diet; but the contributions to dietary fiber from protein feedstuffs may also be substantial. The detergent fiber procedure categorizes fiber into neutral detergent fiber

\footnotetext{
* Corresponding Author: A. O. Adebiyi. Tel: +44-1733422334, Fax: +44-845386420, E-mail: Adekunle.Adebiyi@abagri.com

${ }^{1}$ Department of Veterinary Clinical Sciences, Purdue University, West Lafayette, IN 47907-2054, USA.

2 Department of Animal Sciences, Purdue University, West Lafayette, IN 47907-2054, USA.

Submitted Dec. 2, 2014; Revised Feb. 3, 2015; Accepted Mar. 11, 2015
}

(NDF) that consists of hemicellulose, cellulose and lignin, acid detergent fiber (ADF) that consists of cellulose and lignin and acid detergent lignin (ADL) that consist mainly of lignin (NRC, 2012). The NDF, ADF, and ADL contents in soybean meal (SBM) are $8.2 \%, 5.3 \%$, and $1.1 \%$, respectively (NRC, 2012). Canola meal (CM) may contain up to $35 \%$ crude protein (CP), but the NDF $(23.8 \%)$, ADF $(17.6 \%)$, and $\mathrm{ADL}(7.3 \%)$ contents are greater than are found in SBM (NRC, 2012). Corn distillers dried grains with solubles (corn-DDGS) is the co-product of bioethanol produced from corn grain and may contain up to $27 \% \mathrm{CP}$ (Olukosi and Adebiyi, 2013). The total fiber, NDF, and ADF contents in corn-DDGS are $31 \%, 33 \%$, and $12 \%$, respectively (NRC, 2012).

Excessive nitrogen $(\mathrm{N})$ excretion by pigs may be mitigated by reducing the protein content of the diet (Lee et al., 2001). Lee et al. (2001) noted that reducing dietary CP content by up to 4 percentage units reduced $\mathrm{N}$ excretion by $20 \%$ in finishing pigs. Changes to dietary $\mathrm{CP}$ levels are 
often achieved by wholly replacing or partially substituting SBM with feedstuffs that contain lower CP content. Soybean meal, CM and corn-DDGS were used to determine the effect of differences in diet fiber composition on ileal amino acid (AA) digestibility in the current study because the fiber characteristics of these feedstuffs are different (NRC, 2012). The objective in the current study was to determine the effect of feeding, at two dietary protein levels, three protein feedstuffs that are different in their fiber composition and type on apparent or standardized ileal digestibility (AID or SID) of AA for growing pigs. It was hypothesized that feeding a protein feedstuff with greater fiber content at adequate or low dietary CP level will negatively affect ileal AA digestibility in pigs.

\section{MATERIALS AND METHODS}

\section{Animals, management, diets and sample collection}

All animal handling procedures were approved by the Purdue University Animal Care and Use Committee (USA) and the Animal Experiment Committee of the Scotland's Rural College (UK). Twenty male pigs (Yorkshire $\times$ Landrace) were obtained from the Animal Sciences Research and Education Centre of Purdue University for surgery. The pigs were fasted for 12 hours prior to the surgical procedure of fitting a T-cannula to the distal end of the ileum. The internal diameter, wings and length of the T-cannulas were $1.3,2.5$, and 5 centimeters, respectively. Comprehensive description of the surgical procedure and post-operative care was as described by Dilger et al. (2004). All the pigs were conscious within a short time after the surgery and were allowed a 14-d recovery period.

The average initial body weight (BW) of the pigs was $35 \mathrm{~kg}$ at the start of the current study. The dietary treatments were three protein feedstuffs (SBM, CM, or corn-DDGS) and two protein levels (19\% or $15 \%)$. In each period, two pigs with $\mathrm{BW}$ closest to the mean of the twenty pigs were offered a $\mathrm{N}$-free diet to determine basal endogenous ileal AA flow. The remaining eighteen pigs were allocated to the experimental diets using a triplicated $6 \times 2$ Youden square design. Daily feed allowance was divided into two equal portions and offered in the morning and evening (0800 and 2000, respectively). Pigs were given ad libitum access to water throughout the study. Each experimental period lasted for seven days consisting of five days of adaptation to the diets and two days of ileal digesta collection. Ileal digesta was collected for 12 hours on both days (d 6 and 7). Ileal digesta were collected in Whirlpak bags containing $10 \mathrm{~mL}$ of $10 \%$ formic acid and stored frozen $\left(-20^{\circ} \mathrm{C}\right)$ prior to further analyses. Chromic oxide was added to the diets (5 $\mathrm{g} / \mathrm{kg}$ of diet) as an indigestible marker to enable determination of AID and SID of AA by the index method (Kong and Adeola, 2014). The pigs were housed individually in smooth-walled pens within a facility equipped with temperature, light, and humidity control during the study.

\section{Chemical analysis}

Samples of the diets and ileal digesta were analyzed for dry matter (DM), N, AA, crude fiber (CF), NDF, ADF, and chromium where necessary. Ileal digesta samples were freeze dried before milling and AA analysis. Diet and ileal digesta samples were ground to pass through a $0.5 \mathrm{~mm}$ screen using a mill grinder (Retsch ZM 100, F. Kurt Retsch GmbH \& Co.KG, Haan, Germany) before chemical analysis. Dry matter contents in the diets and ileal digesta were determined by drying samples at $100^{\circ} \mathrm{C}$ for 24 hours. Nitrogen was determined by the combustion method (AOAC International 2006, method 968.06). For AA analyses, samples were hydrolyzed for 24 hours in $6 \mathrm{~N}$ hydrochloric acid at $110^{\circ} \mathrm{C}$ under an atmosphere of N. For Met and Cys, performic acid oxidation was carried out before acid hydrolysis. The AA in the hydrolysate were determined by High Performance Liquid Chromatography after post-column derivatization (AOAC International 2000, method 982.30E [a, b, c]). Chromium was determined using the Inductively Coupled Plasma Atomic Emission Spectroscopy method following nitric/perchloric acid wet ash digestion (AOAC International, 2000, method 990.08). Crude fiber, NDF, and ADF in the diets were determined using the ANKOM's proprietary 200 Filter Bag Technique in Ankom 200 Fiber Analyzer (Ankom Technology, Macedon, NY, USA).

\section{Calculations and statistical analyses}

Apparent ileal digestibility of AA was calculated using the index method. Basal endogenous ileal flow of AA was calculated from a N-free diet using the index method. Standardized ileal digestibility of AA was determined from the correction of AID of AA values for basal endogenous ileal AA losses.

1. Basal ileal AA flow was calculated using the following equation:

$$
\mathrm{EAAF}=\mathrm{AA}_{\mathrm{o}} \times \frac{\mathrm{Cr}_{\mathrm{i}}}{\mathrm{Cr}_{\mathrm{o}}}
$$

Where, EAAF is endogenous ileal AA flow ( $\mathrm{mg} / \mathrm{kg}$ of $\mathrm{DM}$ intake); $\mathrm{AA}_{\mathrm{o}}$ is the AA content in ileal digesta $(\mathrm{mg} / \mathrm{kg})$; $\mathrm{Cr}_{i}$ and $\mathrm{Cr}_{\mathrm{o}}$ are the concentrations of chromium $(\mathrm{mg} / \mathrm{kg})$ in diet and ileal digesta, respectively.

2. AID of AA was calculated using the following equation:

$$
\text { AID of } \mathrm{AA}=\left[1-\left(\frac{\mathrm{Cr}_{\mathrm{i}}}{\mathrm{Cr}_{\mathrm{o}}}\right) \times\left(\frac{\mathrm{AA}_{\mathrm{o}}}{\mathrm{AA}_{\mathrm{i}}}\right)\right] \times 100
$$


Where, AID of AA is apparent ileal digestibility of amino acid (\%); $\mathrm{Cr}_{\mathrm{i}}$ and $\mathrm{Cr}_{\mathrm{o}}$ are the concentrations of chromium in diet and ileal digesta, respectively; $\mathrm{AA}_{0}$ is the amino acid content in the digesta and $\mathrm{AA}_{\mathrm{i}}$ is the amino acid content in the diet.

3. SID of AA was calculated using the following equation:

$$
\text { SID of } A A=A I D+\left[\left(\frac{E A A F}{\mathrm{AA}_{i}}\right) \times 100\right]
$$

Where, SID of AA is standardized ileal digestibility of AA (\%); AID of AA is apparent ileal digestibility of AA (\%); EAAF is the endogenous basal ileal AA flow $(\mathrm{g} / \mathrm{kg}$ of DM intake) and $\mathrm{AA}_{\mathrm{i}}$ is the amino acid content in the diet $(\mathrm{g} / \mathrm{kg}$ of DM).

Data were analyzed using the Generalized Linear
Models of Genstat Statistical Package (11th edition, VSN International) as a triplicated $6 \times 2$ Youden square design. The statistical model for this design was $Y_{\mathrm{ijk}}=\mu+\alpha_{\mathrm{i}}+\beta_{\mathrm{j}}$ $+\gamma_{\mathrm{k}}+(\alpha \beta)_{\mathrm{ij}}+\varepsilon_{\mathrm{ijk}}$ where $\mu$ is the overall mean, $\alpha_{\mathrm{i}}$ is the protein feedstuff effect, $\beta_{\mathrm{j}}$ is the protein level effect, $\gamma_{\mathrm{k}}$ is the block effect, $(\alpha \beta)_{\mathrm{ij}}$ is the interaction effect, and $\varepsilon_{\mathrm{ijk}}$ is the error term. The statistical model for this analysis included replicates with 5 degrees of freedom (df), experimental period with $1 \mathrm{df}$ and dietary treatments with $5 \mathrm{df}$. Individual pig was the experimental unit. Least squares means were separated using the Tukey test with $\mathrm{p}<0.05$ indicating statistical significance.

\section{RESULTS}

The ingredient and chemical composition of the diets used in the current study are presented in Table 1. The digestible energy contents were similar in the diets that

Table 1. Ingredient and chemical composition of diets to determine the effect of protein feedstuff and protein level on apparent or standardized ileal digestibility of amino acids in growing pigs

\begin{tabular}{|c|c|c|c|c|c|c|}
\hline \multirow{2}{*}{ Items } & \multicolumn{3}{|c|}{ Adequate CP } & \multicolumn{3}{|c|}{ Reduced CP } \\
\hline & Soybean meal & Canola meal & Corn-DDGS & Soybean meal & Canola meal & Corn-DDGS \\
\hline \multicolumn{7}{|l|}{ Ingredients } \\
\hline Corn & 67.0 & 58.4 & 42.9 & 77.1 & 72.8 & 63.2 \\
\hline Soybean meal & 26.5 & - & - & 16.0 & - & - \\
\hline Canola meal & - & 37.0 & - & - & 22.0 & - \\
\hline Corn-DDGS & - & - & 51.0 & - & - & 30.0 \\
\hline Soybean oil & 1.20 & - & 0.40 & 1.40 & - & 0.80 \\
\hline Limestone $(38 \% \mathrm{Ca})$ & 1.10 & 1.10 & 1.40 & 1.00 & 1.10 & 1.20 \\
\hline Monocalcium phosphate $^{1}$ & 1.00 & - & 0.50 & 1.30 & 0.60 & 1.00 \\
\hline Common salt & 0.30 & 0.30 & 0.30 & 0.30 & 0.30 & 0.30 \\
\hline Vitamin premix ${ }^{2}$ & 0.15 & 0.15 & 0.15 & 0.15 & 0.15 & 0.15 \\
\hline Mineral premix ${ }^{3}$ & 0.10 & 0.10 & 0.10 & 0.10 & 0.10 & 0.10 \\
\hline Selenium premix ${ }^{4}$ & 0.05 & 0.05 & 0.05 & 0.05 & 0.05 & 0.05 \\
\hline L-Lysine $\mathrm{HCl}$ & 0.10 & 0.40 & 0.70 & 0.10 & 0.40 & 0.70 \\
\hline Chromic oxide premix ${ }^{5}$ & 2.50 & 2.50 & 2.50 & 2.50 & 2.50 & 2.50 \\
\hline Total & 100 & 100 & 100 & 100 & 100 & 100 \\
\hline \multicolumn{7}{|l|}{ Energy and nutrients } \\
\hline Digestible energy (kcal/kg) & 3,442 & 3,489 & 3,442 & 3,442 & 3,412 & 3,412 \\
\hline Crude protein $(\%$, Analyzed $)$ & 19.5 & 19.9 & 19.8 & 15.5 & 15.8 & 15.1 \\
\hline Crude fiber $(\%$, Analyzed $)$ & 3.50 & 6.90 & 5.80 & 3.23 & 4.65 & 3.79 \\
\hline NDF (\%, Analyzed) & 13.5 & 17.2 & 21.6 & 14.2 & 16.7 & 22.6 \\
\hline ADF (\%, Analyzed $)$ & 4.08 & 10.2 & 6.88 & 3.91 & 6.93 & 5.83 \\
\hline ADL (\%, Calculated $)$ & 0.51 & 2.90 & 1.47 & 0.43 & 1.85 & 0.99 \\
\hline Calcium (\%, Calculated) & 0.68 & 0.69 & 0.68 & 0.66 & 0.68 & 0.67 \\
\hline Phosphorus (\%, Calculated) & 0.58 & 0.58 & 0.59 & 0.59 & 0.57 & 0.60 \\
\hline
\end{tabular}

$\mathrm{CP}$, crude protein; Corn-DDGS, corn distillers dried grains with solubles; NDF, neutral detergent fiber; ADF, acid detergent fiber; ADL, acid detergent lignin.

${ }^{1}$ Contained $21 \% \mathrm{Ca}$ and $18 \% \mathrm{P}$.

${ }^{2}$ Vitamin premix contained per kilogram of diet: vitamin A, 2,640 IU; vitamin $\mathrm{D}_{3}$, $264 \mathrm{IU}$; vitamin E, 17.6 IU; vitamin K activity, 2.4 mg; menadione, $880 \mu \mathrm{g}$; vitamin $\mathrm{B}_{12}, 15.4 \mu \mathrm{g}$; riboflavin, $3.52 \mathrm{mg}$; D-pantothenic acid, $8.8 \mathrm{mg}$; niacin, $13.2 \mathrm{mg}$.

${ }^{3}$ Mineral premix contained per kilogram of premix: Cu (as copper chloride), 9 mg; I (as Ethylenediamine Dihydroiodide [EDDI]), 0.36 mg; Fe (as ferrous carbonate), $194 \mathrm{mg}$; Mn (as manganese oxide), $17 \mathrm{mg}$; Zn (as zinc oxide), $149 \mathrm{mg}$.

${ }^{4}$ Selenium premix (supplied $300 \mu \mathrm{g}$ of Se per kilogram of diet).

${ }^{5}$ Chromic oxide premix contained $1 \mathrm{~g}$ chromic oxide added to $4 \mathrm{~g}$ of cornstarch. 
Table 2. Analyzed amino acids composition (dry matter basis) of diets to determine the effect of protein feedstuff and protein level on apparent or standardized ileal digestibility of amino acids in growing pigs

\begin{tabular}{|c|c|c|c|c|c|c|}
\hline \multirow{2}{*}{$\begin{array}{l}\text { Analyzed AA } \\
\text { composition (\%) }\end{array}$} & \multicolumn{3}{|c|}{ Adequate CP } & \multicolumn{3}{|c|}{ Reduced CP } \\
\hline & Soybean meal & Canola meal & Corn-DDGS & Soybean meal & Canola meal & Corn-DDGS \\
\hline \multicolumn{7}{|c|}{ Indispensable amino acids } \\
\hline Arg & 1.25 & 1.21 & 1.01 & 1.01 & 0.93 & 0.83 \\
\hline His & 0.52 & 0.58 & 0.59 & 0.45 & 0.47 & 0.48 \\
\hline Ile & 0.83 & 0.83 & 0.79 & 0.70 & 0.64 & 0.65 \\
\hline Leu & 1.84 & 1.85 & 2.54 & 1.63 & 1.59 & 2.06 \\
\hline Lys & 1.08 & 1.33 & 1.15 & 0.90 & 1.11 & 1.15 \\
\hline Met & 0.30 & 0.44 & 0.42 & 0.29 & 0.32 & 0.33 \\
\hline Phe & 0.99 & 0.93 & 1.02 & 0.83 & 0.75 & 0.85 \\
\hline Thr & 0.73 & 0.83 & 0.75 & 0.59 & 0.65 & 0.60 \\
\hline $\operatorname{Trp}$ & 0.25 & 0.25 & 0.18 & 0.19 & 0.18 & 0.15 \\
\hline Val & 0.94 & 1.09 & 1.06 & 0.80 & 0.84 & 0.85 \\
\hline \multicolumn{7}{|c|}{ Dispensable amino acids } \\
\hline Ala & 1.06 & 1.13 & 1.54 & 0.95 & 0.97 & 1.26 \\
\hline Asp & 1.87 & 1.47 & 1.37 & 1.47 & 1.14 & 1.15 \\
\hline Cys & 0.30 & 0.46 & 0.40 & 0.29 & 0.35 & 0.32 \\
\hline Glu & 3.64 & 3.81 & 3.48 & 3.07 & 3.10 & 3.04 \\
\hline Gly & 0.82 & 1.01 & 0.88 & 0.67 & 0.77 & 0.70 \\
\hline Pro & 1.26 & 1.48 & 1.70 & 1.11 & 1.25 & 1.42 \\
\hline Ser & 0.83 & 0.79 & 0.81 & 0.69 & 0.67 & 0.66 \\
\hline Tyr & 0.67 & 0.63 & 0.72 & 0.55 & 0.53 & 0.61 \\
\hline Total & 19.2 & 20.3 & 20.6 & 16.3 & 16.4 & 17.2 \\
\hline
\end{tabular}

AA, amino acids; CP, crude protein; Corn-DDGS, corn distillers dried grains with solubles.

contained adequate or reduced CP levels. Regardless of CP level, analyzed CF, NDF, and ADF were lowest in the SBM diet. On the other hand, the CM diet contained the greatest levels of ADF and ADL whereas NDF was greatest in the corn-DDGS diet. The analyzed AA content of the diets used in the current study are presented in Table 2 . The analyzed AA contents in the diets were similar to calculated values and mirrored the difference in the $\mathrm{CP}$ contents between the adequate and reduced $\mathrm{CP}$ diets. The ingredient and chemical composition of the $\mathrm{N}$-free diet used to determine basal endogenous ileal AA flow is presented in Table 3. As was expected, the $\mathrm{CP}$ and $\mathrm{AA}$ content in the $\mathrm{N}$-free diet were either nil or very low.

Dry matter digestibility and AID of $\mathrm{N}$ and indispensable $\mathrm{AA}$ in growing pigs receiving diets with different protein feedstuffs and CP levels are presented in Table 4. Reducing dietary CP level from 19\% to $15 \%$ did not affect ileal DM digestibility or AID of AA in growing pigs. Ileal DM digestibility was greater $(\mathrm{p}<0.05)$ in the SBM diet compared with either the CM diet or corn-DDGS diet. With the exception of Met and Trp, AID of AA was greater $(p<0.05)$ in the SBM diet compared with the CM diet. The AID of Ile, Leu, Phe, and Val were greater $(\mathrm{p}<0.05)$ in the corn-DDGS diet compared with the CM diet. Apparent ileal digestibility of AA was similar in the SBM diet and the corn-DDGS diet. There was protein feedstuff $\times$ protein level interaction $(\mathrm{p}<0.05)$ for AID of Lys. The AID of Lys was greater $(p<0.05)$ in the SBM and corn-DDGS diets compared with the $\mathrm{CM}$ diet in $\mathrm{CP}$-adequate dietary treatments, whereas the AID of Lys did not differ among the reduced-CP dietary treatments.

Apparent ileal digestibility for dispensable AA and total amino acids (TAA) in growing pigs receiving diets containing the different protein feedstuffs and CP levels are presented in Table 5. Reducing dietary CP level from 19\% to $15 \%$ did not affect AID of AA in growing pigs. Apparent ileal digestibility of Gly and Asp were greater $(p<0.05)$ in the SBM diet compared with the corn-DDGS diet. With the exception of Cys and Pro, AID of AA was greater $(p<0.05)$ in the SBM diet compared with the CM diet. The AID of Ala, Tyr, and Asp were greater in the corn-DDGS diet compared with the CM diet. The AID of TAA was greater $(\mathrm{p}<0.05)$ in the SBM diet compared with the CM diet, but did not differ significantly from that of the corn-DDGS diet.

The standardized ileal digestibility of $\mathrm{N}$ and indispensable AA in growing pigs receiving diets containing different protein feedstuffs and $\mathrm{CP}$ levels are presented in Table 6. Reducing dietary CP level from $19 \%$ to $15 \%$ did not affect SID of AA in growing pigs. Except for Trp, SID of AA was greater $(p<0.05)$ in the SBM diet compared with the CM diet. The SID of Ile, Leu, and Val were greater $(\mathrm{p}<0.05)$ in the corn-DDGS diet compared with the CM diet. 
Table 4. Dry matter digestibility and apparent ileal digestibility (\%) of nitrogen and indispensable amino acids in growing pigs in response to protein feedstuff used and crude protein level

\begin{tabular}{|c|c|c|c|c|c|c|c|c|c|c|c|c|}
\hline & DM & $\mathrm{N}$ & Arg & His & Ile & Leu & Lys & Phe & Thr & Met & Trp & Val \\
\hline \multicolumn{13}{|l|}{ Effect of protein feedstuff ${ }^{2}$} \\
\hline Soybean meal & $67.9^{\mathrm{b}}$ & $74.2^{\mathrm{b}}$ & $86.3^{\mathrm{b}}$ & $83.3^{\mathrm{b}}$ & $79.7^{\mathrm{b}}$ & $82.3^{\mathrm{b}}$ & $82.2^{\mathrm{b}}$ & $81.6^{\mathrm{b}}$ & $69.7^{\mathrm{b}}$ & 83.4 & 79.4 & $74.1^{\mathrm{b}}$ \\
\hline Canola meal & $56.5^{\mathrm{a}}$ & $62.0^{\mathrm{a}}$ & $79.4^{\mathrm{a}}$ & $75.0^{\mathrm{a}}$ & $66.8^{\mathrm{a}}$ & $73.1^{\mathrm{a}}$ & $72.0^{\mathrm{a}}$ & $71.3^{\mathrm{a}}$ & $56.4^{\mathrm{a}}$ & 77.4 & 74.6 & $62.6^{\mathrm{a}}$ \\
\hline Corn-DDGS & $57.0^{\mathrm{a}}$ & $69.0^{\mathrm{ab}}$ & $81.4^{\mathrm{ab}}$ & $78.8^{\mathrm{ab}}$ & $74.6^{\mathrm{b}}$ & $82.3^{\mathrm{b}}$ & $77.4^{\mathrm{ab}}$ & $78.5^{\mathrm{b}}$ & $64.1^{\mathrm{ab}}$ & 81.5 & 72.4 & $71.4^{\mathrm{b}}$ \\
\hline SEM & 2.98 & 2.04 & 1.48 & 1.61 & 1.93 & 1.82 & 1.51 & 1.96 & 2.45 & 1.71 & 1.79 & 2.08 \\
\hline \multicolumn{13}{|l|}{ Effect of crude protein level ${ }^{3}$} \\
\hline Adequate (19\% CP) & 60.2 & 70.2 & 83.6 & 79.7 & 74.3 & 79.8 & 76.7 & 77.7 & 65.0 & 82.2 & 77.3 & 70.3 \\
\hline Reduced (15\% CP) & 61.0 & 66.8 & 81.3 & 78.5 & 73.4 & 78.9 & 78.0 & 76.8 & 62.1 & 79.4 & 73.5 & 68.8 \\
\hline SEM & 2.44 & 1.70 & 1.21 & 1.32 & 1.58 & 1.48 & 1.23 & 1.61 & 2.00 & 1.40 & 1.46 & 1.71 \\
\hline \multicolumn{13}{|c|}{$\mathrm{p}$-values for main effects and interaction } \\
\hline Protein feedstuff & 0.030 & 0.009 & 0.017 & 0.013 & $<0.001$ & 0.002 & 0.002 & 0.003 & 0.009 & 0.068 & 0.102 & 0.005 \\
\hline Protein level & 0.823 & 0.261 & 0.227 & 0.578 & 0.699 & 0.678 & 0.532 & 0.697 & 0.389 & 0.190 & 0.170 & 0.573 \\
\hline Feedstuff $\times$ protein level & 0.461 & 0.233 & 0.208 & 0.267 & 0.388 & 0.379 & 0.045 & 0.391 & 0.321 & 0.813 & 0.333 & 0.359 \\
\hline
\end{tabular}

DM, dry matter; corn-DDGS, corn distillers dried grains with solubles; SEM, standard error of the mean; CP, crude protein.

${ }^{1}$ Values are mean of 6 replicates.

${ }^{2}$ For the effect of protein feedstuff, within a column, means followed by same or no superscript do not differ ( $p>0.05$ ).

${ }^{3}$ For the effect of crude protein level, within a column, means followed by same or no superscript do not differ ( $\mathrm{p}>0.05$ ).

inferior AID of AA or SID of AA observed in the CM diet compared with the SBM diet was due to the anti-nutritive effects of the ADF fraction in the $\mathrm{CM}$ diet. On the other hand, there were minimal differences between the AID of $\mathrm{AA}$ or SID of AA of SBM and corn-DDGS diets considering that the latter contained greater levels of hemicellulose. It is possible however, that the differences in hemicellulose contents in the SBM and corn-DDGS diets was not large enough to negatively affect AID or SID of AA in the current study.

The nutritional gain from $\mathrm{N}$ degraded in the large intestine of growing pigs is limited (Sauer et al., 1991). Because excessive loss of $\mathrm{N}$ in pig manure is detrimental to the environment, interventions that do not affect AA digestibility but reduces undigested protein flow to the large intestine are of particular interest. In the current study, reducing dietary $\mathrm{CP}$ level by 4 percentage units did not affect ileal AA digestibility. Otto et al. (2003) on the other hand, reported an increase in ileal AA digestibility in growing pigs receiving a corn-SBM diet containing $6 \% \mathrm{CP}$. The difference in ileal AA digestibility response to reduction in dietary $\mathrm{CP}$ in the current study and Otto et al.

Table 5. Apparent ileal digestibility (\%) of total- and dispensable amino acids in growing pigs in response to protein feedstuff used and crude protein level ${ }^{1}$

\begin{tabular}{|c|c|c|c|c|c|c|c|c|c|}
\hline & Ala & Cys & Glu & Gly & Pro & Ser & Tyr & Asp & TAA \\
\hline \multicolumn{10}{|l|}{$\overline{\text { Effect of protein feedstuff }}{ }^{2}$} \\
\hline Soybean meal & $75.9^{\mathrm{b}}$ & 73.2 & $84.8^{\mathrm{b}}$ & $69.1^{\mathrm{b}}$ & 67.1 & $76.9^{\mathrm{b}}$ & $79.9^{\mathrm{b}}$ & $77.4^{\mathrm{c}}$ & $77.9^{\mathrm{b}}$ \\
\hline Canola meal & $67.4^{\mathrm{a}}$ & 64.0 & $78.3^{\mathrm{a}}$ & $58.1^{\mathrm{a}}$ & 64.6 & $63.8^{\mathrm{a}}$ & $69.3^{\mathrm{a}}$ & $60.4^{\mathrm{a}}$ & $68.2^{\mathrm{a}}$ \\
\hline Corn-DDGS & $77.3^{\mathrm{b}}$ & 71.5 & $81.4^{\mathrm{ab}}$ & $59.1^{\mathrm{a}}$ & 74.1 & $71.3^{\mathrm{ab}}$ & $77.7^{\mathrm{b}}$ & $68.4^{\mathrm{b}}$ & $74.9^{\mathrm{ab}}$ \\
\hline SEM & 1.87 & 2.05 & 1.59 & 2.55 & 3.23 & 2.04 & 1.87 & 2.08 & 1.80 \\
\hline \multicolumn{10}{|l|}{ Effect of crude protein level ${ }^{3}$} \\
\hline Adequate $(19 \% \mathrm{CP})$ & 74.3 & 70.1 & 82.1 & 64.1 & 71.7 & 71.5 & 76.5 & 69.2 & 74.7 \\
\hline Reduced (15\% CP) & 73.0 & 69.4 & 81.1 & 60.2 & 65.5 & 70.2 & 75.1 & 68.8 & 73.0 \\
\hline SEM & 1.53 & 1.68 & 1.30 & 2.09 & 2.65 & 1.67 & 1.53 & 1.69 & 1.47 \\
\hline \multicolumn{10}{|c|}{ p-values for main effects and interaction } \\
\hline Protein feedstuff & 0.007 & 0.057 & 0.041 & 0.006 & 0.111 & 0.002 & 0.002 & $<0.001$ & 0.017 \\
\hline Protein level & 0.582 & 0.838 & 0.644 & 0.182 & 0.106 & 0.625 & 0.548 & 0.911 & 0.529 \\
\hline Feedstuff $\times$ protein level & 0.331 & 0.492 & 0.442 & 0.586 & 0.652 & 0.220 & 0.264 & 0.233 & 0.223 \\
\hline
\end{tabular}

TAA, total amino acids; corn-DDGS, corn distillers dried grains with solubles; SEM, standard error of the mean; CP, crude protein.

${ }^{1}$ Values are mean of 6 replicates.

${ }^{2}$ For the effect of protein feedstuff, within a column, means followed by same or no superscript do not differ ( $\left.\mathrm{p}>0.05\right)$.

${ }^{3}$ For the effect of crude protein level, within a column, means followed by same or no superscript do not differ ( $p>0.05$ ). 
Table 6. Standardized ileal digestibility (\%) of nitrogen and indispensable amino acids in growing pigs in response to protein feedstuff used and crude protein level ${ }^{1}$

\begin{tabular}{|c|c|c|c|c|c|c|c|c|c|c|c|}
\hline & $\mathrm{N}$ & Arg & His & Ile & Leu & Lys & Phe & Thr & Met & Trp & Val \\
\hline \multicolumn{12}{|l|}{ Effect of protein feedstuff $^{2}$} \\
\hline Soybean meal & $81.2^{\mathrm{b}}$ & $90.4^{\mathrm{b}}$ & $86.3^{\mathrm{b}}$ & $83.2^{\mathrm{b}}$ & $84.9^{\mathrm{b}}$ & $86.3^{\mathrm{b}}$ & $84.7^{\mathrm{b}}$ & $76.4^{\mathrm{b}}$ & $87.8^{\mathrm{b}}$ & 83.9 & $79.5^{\mathrm{b}}$ \\
\hline Canola meal & $68.8^{\mathrm{a}}$ & $83.7^{\mathrm{a}}$ & $77.8^{\mathrm{a}}$ & $70.5^{\mathrm{a}}$ & $75.8^{\mathrm{a}}$ & $75.4^{\mathrm{a}}$ & $74.6^{\mathrm{a}}$ & $62.4^{\mathrm{a}}$ & $79.5^{\mathrm{a}}$ & 79.3 & $67.5^{\mathrm{a}}$ \\
\hline Corn-DDGS & $76.0^{\mathrm{ab}}$ & $86.4^{\mathrm{ab}}$ & $81.6^{\mathrm{ab}}$ & $78.3^{\mathrm{b}}$ & $84.3^{\mathrm{b}}$ & $80.9^{\mathrm{ab}}$ & $81.5^{\mathrm{ab}}$ & $70.6^{\mathrm{ab}}$ & $84.5^{\mathrm{ab}}$ & 78.4 & $76.3^{b}$ \\
\hline SEM & 2.02 & 1.51 & 1.61 & 1.98 & 1.81 & 1.53 & 1.92 & 2.46 & 1.68 & 1.82 & 2.07 \\
\hline \multicolumn{12}{|l|}{ Effect of crude protein level ${ }^{3}$} \\
\hline Adequate $(19 \% \mathrm{CP})$ & 76.4 & 87.6 & 82.3 & 77.6 & 82.1 & 80.2 & 80.6 & 70.7 & 83.9 & 81.8 & 74.9 \\
\hline Reduced $(15 \% \mathrm{CP})$ & 74.6 & 86.2 & 81.7 & 77.4 & 81.6 & 81.9 & 80.3 & 69.3 & 81.6 & 79.3 & 74.4 \\
\hline SEM & 1.65 & 1.24 & 1.32 & 1.62 & 1.49 & 1.25 & 1.58 & 2.01 & 1.39 & 1.48 & 1.70 \\
\hline \multicolumn{12}{|c|}{$\mathrm{p}$-values for main effects and interaction } \\
\hline Protein feedstuff & 0.008 & 0.026 & 0.010 & $<0.001$ & 0.002 & $<0.001$ & 0.004 & 0.006 & 0.047 & 0.205 & 0.004 \\
\hline Protein level & 0.561 & 0.482 & 0.764 & 0.940 & 0.807 & 0.397 & 0.886 & 0.673 & 0.253 & 0.363 & 0.866 \\
\hline Feedstuff $\times$ protein level & 0.225 & 0.191 & 0.258 & 0.359 & 0.371 & 0.055 & 0.375 & 0.314 & 0.760 & 0.315 & 0.333 \\
\hline
\end{tabular}

Corn-DDGS, corn distillers dried grains with solubles; SEM, standard error of the mean; CP, crude protein.

${ }^{1}$ Values are mean of 6 replicates.

${ }^{2}$ For the effect of protein feedstuff, within a column, means followed by same or no superscript do not differ ( $\left.p>0.05\right)$.

${ }^{3}$ For the effect of crude protein level, within a column, means followed by same or no superscript do not differ ( $\left.\mathrm{p}>0.05\right)$.

(2003) study may be because there was a much greater reduction in dietary $\mathrm{CP}$ level in the latter which may have triggered a greater response from pigs in order to meet nutrient requirement.

Except for the AID of Lys, there was no interaction between protein feedstuff and CP level on ileal AA digestibility in the current study. The interaction observed for the AID of Lys was due to a reduction in the AID of Lys from $85 \%$ in the $\mathrm{CP}$-adequate $\mathrm{SBM}$ diet to $79 \%$ in the reduced-CP SBM diet. Notably, reducing the CP level in the SBM diet by 4 percentage units reduced the Lys content from $1.08 \%$ to $0.90 \%$ but caused minimal changes to dietary fiber levels. It is possible that the increase in dietary fiber content relative to Lys composition in the reduced-CP SBM diet was responsible for the reduction in the AID of Lys. Htoo et al. (2007) on the other hand, reported a decrease in AID of AA (except Lys, Met, Thr, Val, and Pro) with a reduction in dietary CP from $24 \%$ to $20 \%$. Differences in feedstuff and dietary protein levels used in the current study and that of Htoo et al. (2007) are factors that may affect ileal AA digestibility response to changes in CP level.

It was concluded that the type and level of dietary fiber affect ileal AA digestibility in growing pigs, and the choice

Table 7. Standardized ileal digestibility (\%) of total- and dispensable amino acids in growing pigs in response to protein feedstuff used and crude protein level ${ }^{1}$

\begin{tabular}{|c|c|c|c|c|c|c|c|c|c|}
\hline & Ala & Cys & Glu & Gly & Pro & Ser & Tyr & Asp & TAA \\
\hline \multicolumn{10}{|l|}{ Effect of protein feedstuff ${ }^{2}$} \\
\hline Soybean meal & $80.9^{\mathrm{b}}$ & $77.6^{\mathrm{b}}$ & $87.2^{\mathrm{b}}$ & $85.0^{\mathrm{b}}$ & 87.4 & $82.3^{\mathrm{b}}$ & $83.6^{\mathrm{b}}$ & $81.4^{\mathrm{c}}$ & $84.3^{\mathrm{b}}$ \\
\hline Canola meal & $72.2^{\mathrm{a}}$ & $67.2^{\mathrm{a}}$ & $80.6^{\mathrm{a}}$ & $71.5^{\mathrm{a}}$ & 82.3 & $69.5^{\mathrm{a}}$ & $73.1^{\mathrm{a}}$ & $65.6^{\mathrm{a}}$ & $74.4^{\mathrm{a}}$ \\
\hline Corn-DDGS & $80.9^{\mathrm{b}}$ & $75.1^{\mathrm{ab}}$ & $83.8^{\mathrm{ab}}$ & $74.1^{\mathrm{a}}$ & 89.6 & $77.0^{\mathrm{ab}}$ & $81.0^{\mathrm{b}}$ & $73.7^{\mathrm{b}}$ & $80.9^{\mathrm{ab}}$ \\
\hline SEM & 1.90 & 2.01 & 1.59 & 2.60 & 3.18 & 2.02 & 1.86 & 2.09 & 1.75 \\
\hline \multicolumn{10}{|l|}{ Effect of crude protein level ${ }^{3}$} \\
\hline Adequate $(19 \% \mathrm{CP})$ & 78.5 & 73.5 & 84.2 & 77.3 & 88.2 & 76.6 & 79.8 & 73.4 & 80.3 \\
\hline Reduced (15\% CP) & 77.8 & 73.5 & 83.7 & 76.8 & 84.8 & 76.3 & 79.0 & 74.2 & 79.8 \\
\hline SEM & 1.56 & 1.65 & 1.30 & 2.13 & 2.61 & 1.65 & 1.52 & 1.71 & 1.43 \\
\hline \multicolumn{10}{|c|}{ p-values for main effects and interaction } \\
\hline Protein feedstuff & 0.011 & 0.031 & 0.039 & 0.001 & 0.274 & 0.002 & 0.003 & $<0.001$ & 0.015 \\
\hline Protein level & 0.772 & 0.993 & 0.793 & 0.869 & 0.370 & 0.923 & 0.738 & 0.807 & 0.845 \\
\hline Feedstuff $\times$ protein level & 0.315 & 0.437 & 0.433 & 0.595 & 0.629 & 0.226 & 0.271 & 0.218 & 0.210 \\
\hline
\end{tabular}

TAA, total amino acids; Corn-DDGS, corn distillers dried grains with solubles; SEM, standard error of the mean; CP, crude protein.

${ }^{1}$ Values are mean of 6 replicates.

${ }^{2}$ For the effect of protein feedstuff, within a column, means followed by same or no superscript do not differ ( $\left.p>0.05\right)$.

${ }^{3}$ For the effect of crude protein level, within a column, means followed by same or no superscript do not differ ( $\mathrm{p}>0.05$ ). 
of protein feedstuff explains some of the differences in dietary fiber type and level. The use of either SBM or cornDDGS as protein feedstuff in the growing pig diet produced similar ileal AA digestibility but CM was inferior to both SBM and corn-DDGS. In addition, reducing dietary protein level from $19 \%$ to $15 \%$ does not affect ileal AA digestibility in growing pigs.

\section{ACKNOWLEDGMENTS}

The authors acknowledge assistance by Richard Byrd for care of pigs and laboratory technical assistance by Pat Jaynes and Ahmet Pekel.

Adekunle Adebiyi was a visiting scholar at Department of Animal Sciences, Purdue University, West Lafayette, Indiana, USA from February 2013 to August 2013 as part of a PhD studentship sponsored by Home Grown Cereals Authority, Kenilworth, UK.

\section{REFERENCES}

AOAC International. 2000. Official Methods of Analysis. 17th ed. Association Official Analytical Chemists, Arlington, VA, USA.

AOAC International. 2006. Official Methods of Analysis. 18th ed. Association Official Analytical Chemists, Arlington, VA, USA.

Choct, M., A. Kocher, D. L. E. Waters, D. Pettersson, and G. Ross. 2004. A comparison of three xylanases on the nutritive value of two wheats for broiler chickens. Br. J. Nutr. 92:53-61.

Dierick, N., I. Vervaeke, J. Decuypere, and H. Hendericks. 1983. Influence of the nature and level of crude fibres on the apparent ileal and fecal digestibility of dry matter, proteins and amino acids and on the nitrogen retention in swine. Revue de 1'Agriculture 36:1691-1712.

Dilger, R. N., J. S. Sands, D. Ragland, and O. Adeola. 2004. Digestibility of nitrogen and amino acids in soybean meal with added soyhulls. J. Anim. Sci. 82:715-724.

Htoo, J. K., B. A. Araiza, W. C. Sauer, M. Rademacher, Y. Zhang, M. Cervantes, and R. T. Zijlistra. 2007. Effect of dietary protein content on ileal amino acid digestibility, growth performance, and formation of microbial metabolites in ileal and cecal digesta of early-weaned pigs. J. Anim. Sci. 85:33033312 .
Kong, C. and O. Adeola. 2014. Evaluation of amino acid and energy utilization in feedstuff for swine and poultry diets. Asian Australas. J. Anim. Sci. 27:917-925

Lee, J. H., J. H. Kim, J. D. Kim, S. W. Kim, and In K. Han. 2001. Effects of low crude protein diets supplemented with synthetic amino acids on performance, nutrient utilization and carcass characteristics in finishing pigs reared using a phase feeding regimen. Asian Australas. J. Anim. Sci. 14:655-667.

Lenis, N. P., P. Bikker, J. van der Meulen, J. T. van Diepen, J. G. Bakker, and A. W. Jongbloed. 1996. Effect of dietary neutral detergent fiber on ileal digestibility and portal flux of nitrogen and amino acids and on nitrogen utilization in growing pigs. J. Anim. Sci. 74:2687-2699.

Mosenthin, R., W. C. Sauer, and F. Ahrens. 1994. Dietary pectin's effect on ileal and fecal amino acid digestibility and exocrine pancreatic secretions in growing pigs. J. Nutr. 124:1222-1229.

National Research Council. 2012. Nutrient Requirements of Swine. 11 th ed. The Natl. Acad. Press, Washington, DC, USA.

Olukosi, O. A. and A. O. Adebiyi. 2013. Chemical composition and prediction of amino acid content of maize- and wheatdistillers' dried grains with soluble. Anim. Feed Sci. Technol. 185:182- 189 .

Otto, E. R., M. Yokoyama, P. K. Ku, N. K. Ames, and N. L. Trottier. 2003. Nitrogen balance and ileal amino acid digestibility in growing pigs fed diets reduced in protein concentration. J. Anim. Sci. 81:1743-1753.

Sauer, W. C., R. Mosenthin, F. Ahrens, and L. A. den Hartog. 1991. The effect of source of fiber on ileal and fecal amino acid digestibility and bacterial nitrogen excretion in growing pigs. J. Anim. Sci. 69:4070-4077.

Wenk, C. 2001. The role of dietary fibre in the digestive physiology of the pig. Anim. Feed Sci. Technol. 90:21-33.

Wilfart, A., L. Montagne, P. H. Simmins, J. van Milgen, and J. Noblet. 2007. Sites of nutrient digestion in growing pigs: Effect of dietary fiber. J. Anim. Sci. 85:976-983.

Zhang, W., D. Li, L. Liu, J. Zang, Q. Duan, W. Yang, and L. Zhang. 2013. The effects of dietary fiber level on nutrient digestibility in growing pigs. J. Anim. Sci. Biotechnol. 4:17.

Zervas, S. and R. T. Zijlstra. 2002. Effects of dietary protein and fermentable fiber on nitrogen excretion patterns and plasma urea in grower pigs. J. Anim. Sci. 80:3247-3256. 